\title{
Ovarian Sertoliform Endometrioid Adenocarcinoma: A Rare Variant Which Causes Diagnostic Pitfalls
}

\author{
Over Sertoliform Endometrioid Adenokarsinomu: Tanisal Tuzak Olușturan Nadir Bir Varyant
}

Duygu Kankaya ${ }^{1}$, Korhan Kahraman², Fırat Ortaç², Arzu Ensari ${ }^{1}$

Departments of Pathology, and Gynecology, Medical School of Ankara University, Ankara.

Departments of Obstetrics and Gynecology, Medical School of Ankara University, Ankara.
Received : Dec 08,2015 • Accepted: Sep 30,2015

\section{Corresponding Author}

Duygu Kankaya, Asst. Prof. Phone: +90 3125958103

E-mail: duygu.kankaya@gmail.com

Ankara University, School of Medicine Department of Pathology Sihhiye, Ankara, Turkey, 06100.

Sertoliform endometrioid carcinoma (SEC) is a rare variant of endometrioid adenocarcinoma, which causes diagnostic pitfalls due to its morphologic resemblance of sex cord stromal tumors. Herein, we report a case of SEC in the ovary almost all of which consisted of sex-cord like areas and was presumed to be a sertoli cell tumour initially. Immunohistochemical features incompatible with sertoli cell tumour were alerting and extensive sampling revealed a focal component of classical endometrioid carcinoma with anastomosing cribriform areas of more columnar cells. The final diagnosis was sertoliform endometrioid adenocarcinoma. This entity should be kept in mind for all the pathologists and gynaecologic oncologists. Sampling such tumours extensively and confirming the diagnosis by immunohistochemistry using a large antibody panel is requisite for the correct diagnosis and preventing the patient from inappropriate therapies.

Key Words: Endometrioid Adenocarcinoma, Ovary, Sertoli Cell Tumour, Differential Diagnosis

Sertoliform endometrioid karsinoma (SEK), endometrioid adenokarsinomanın nadir görülen bir varyantı olup, seks kord stromal tümöre morfolojik benzerlikleri nedeniyle tanısal tuzak olușturur. Burada, neredeyse tamamı seks kord benzeri alanlardan olușan ve bașlangıçta sertoli hücreli tümör olarak düșünülen over SEK'sına ait bir olgu sunulmuștur. Sertoli hücreli tümör ile uyumlu olmayan immunohistokimyasal özellikler uyarıcı olmuș ve makroskopik olarak çok geniș örnekleme yapılmıștır, Fokal bir komponent olarak anastomozlașan kribriform alanlar meydana getiren daha kolumnar özellikte hücrelerle karakterli klasik endometrioid karsinoma alanlarının saptanması üzerine olgu sertoliform endometrioid adenokarsinoma olarak raporlanmıstır. Bu antitenin tüm patologlar ve jinekolojik onkologlar tarafından akılda tutulması gerekir. Bu tümörlerde doğru tanıya ulașılabilmesi ve dolayısıyla hastaların yanlıș tedavilerden korunabilmesi açısından, geniș makroskopik örneklemeyle inceleme yapılması ve geniș bir antikor paneliyle immunohistokimyasal doğrulama çok önemlidir.

Anahtar Sözcükler: Endometrioid Adenokarsinoma, Over, Sertoli Hücreli Tümör, Ayırıcı Tanı

Sertoliform endometrioid carcinoma

(SEC) is a rare variant of endometrioid carcinoma, which was first described in the ovary by Young et al and Roth et al, separately, in $1982(1,2)$. Then Fox et al defined the first case of endometrium (3) and to date, nearly 80 cases of the ovary $(1,2,4-9)$ and nearly 20 cases of the endometrium $(3,10,11-14)$ were reported in the literature. Its morphologic similarity to sex cord stromal tumors such as sertoli cell tumor, sertoli- leydig cell tumor or rarely granulosa cell tumor causes diagnostic pitfall for the pathologist. Despite the clinical differences of sex cord stromal tumors with younger age and virilizing signs, patients with
SEC may, however, present with virilizing signs that may also lead to an incorrect clinical diagnosis (4).

Most of the immunohistochemical studies support the epithelial nature of these sex cord-like cells with epithelial membrane antigen (EMA), cytokeratin (CK) positivity and inhibin alpha negativity, however in a case of SEC localized in the endometrium, true sex cord differentiation with inhibin $\alpha$ positivity has been reported and it has been suggested that endometrial carcinoma, similar to other mullerian tumors, has multipotentiality and can undergo true sex cord differentiation $(4-6,15,16)$. 
Herein, we report a case of SEC in the ovary almost all of which consisted of sex-cord like areas and was presumed to be a sertoli cell tumour initially. Then the final diagnosis of SEC was reached by the help of immunohistochemical findings and detection of minor typical endometrioid carcinoma foci by extensive sampling.

\section{Case Report}

A 62-year-old multiparous woman presented with an unilateral adnexal mass and elevated serum CA-125 level. Surgical staging procedure for ovarian malignancy was performed without an intraoperative frozen section analysis. Macroscopic examination revealed a tumor on the left ovary, $8 \mathrm{~cm}$ in long diameter. It had an heterogenous appearance with solid and cystic components and foci of necrosis and hemorrhage. There was infiltration of the ovarian capsule extensively. Microscopically, the main architecture of the tumor was anastomosing cords and trabeculae, tightly packed nests and rare solid or hollow tubules of cells with vesicular, oval or rounded nuclei, prominent nucleoli (Fig.1). They showed moderate pleomorphism and high mitotic activity. Extensive necrosis and hemorrhage were detected. Considering morphological properties, it was initially evaluated as a sertoli cell tumor. As some other gynaecologic neoplasms may also show sex cord-like areas, further examination was required for confirmation. An immunohistochemical study including pan-cytokeratin (PANCK) (Novocastra, clone 5D3 and LP34, 1:50), cytokeratin 7 (CK7) (CellMarque, clone OV-TL 12/30, 1:200), cytokeratin $20 \quad$ (CK20) (CellMarque, clone Ks20.8, 1:200), inhibin $\alpha$ (Neomarkers, clone R1, $1: 10)$, calretinin (Neomarkers, clone 5A5, 1:75), epithelial membrane antigen (EMA) (Neomarkers, clone GP1.4, 1:1000), estrogene receptor (ER) (Neomarkers, clone SP1, 1:150) and progesterone receptor (PR) (Neomarkers, clone SP2, 1:25) antibodies was performed by using
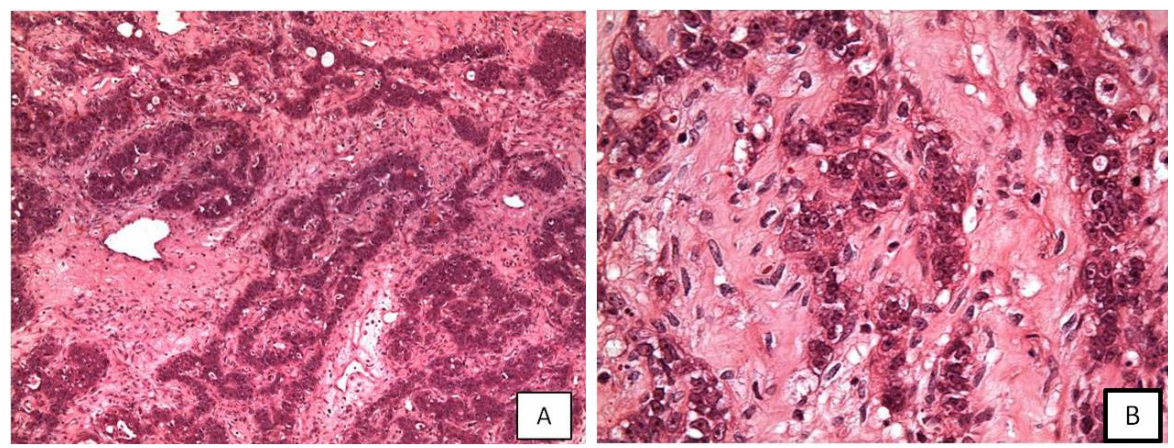

Figure 1: Anastomosing cords and trabeculae of tumour cells (A) with vesicular, oval or rounded nuclei and prominent nucleoli (B) (H\&E x10, x40).
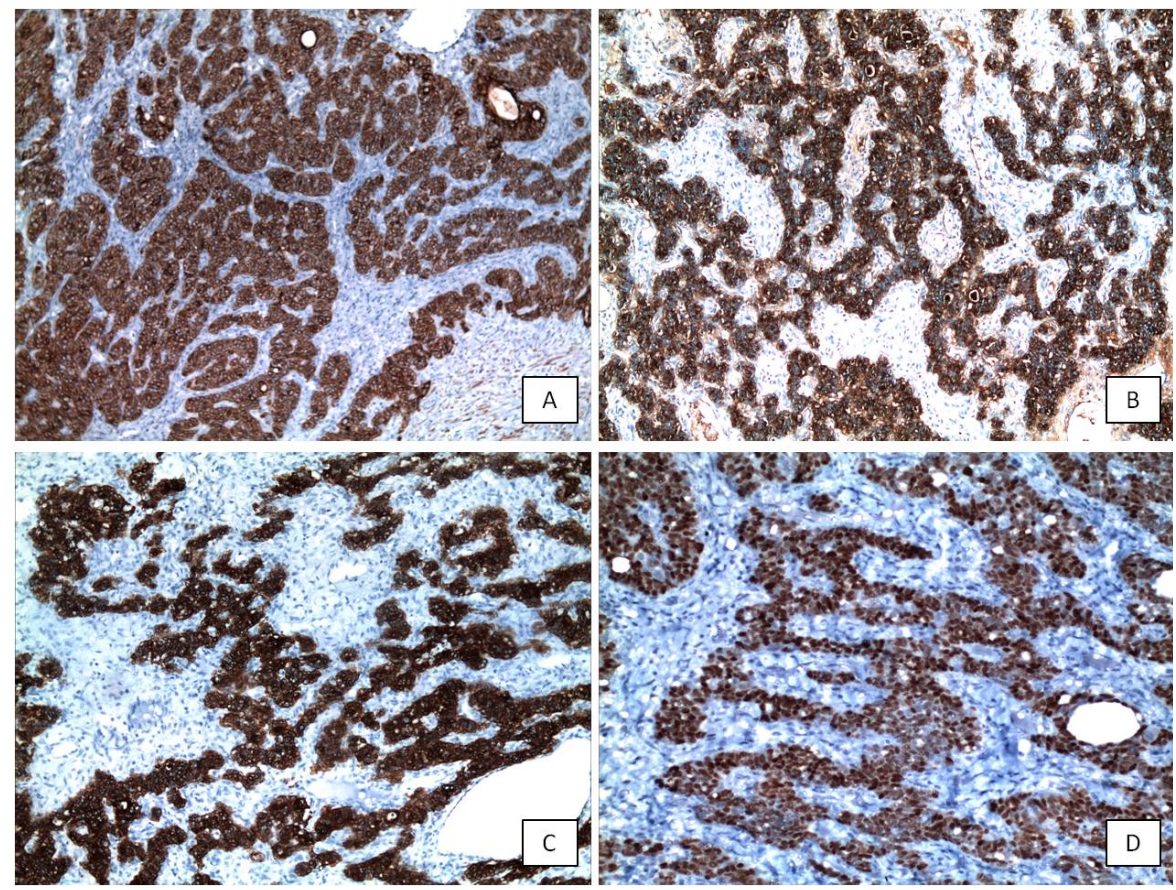

Figure 2: Tumour cells show strong and diffuse positivity with pancytokeratin $(A)$, epithelial membrane antigen (B), cytokeratin $7(C)$ and estrogene receptor (D) (x10, $\mathrm{x} 10, \mathrm{x} 10, \mathrm{x} 20)$.

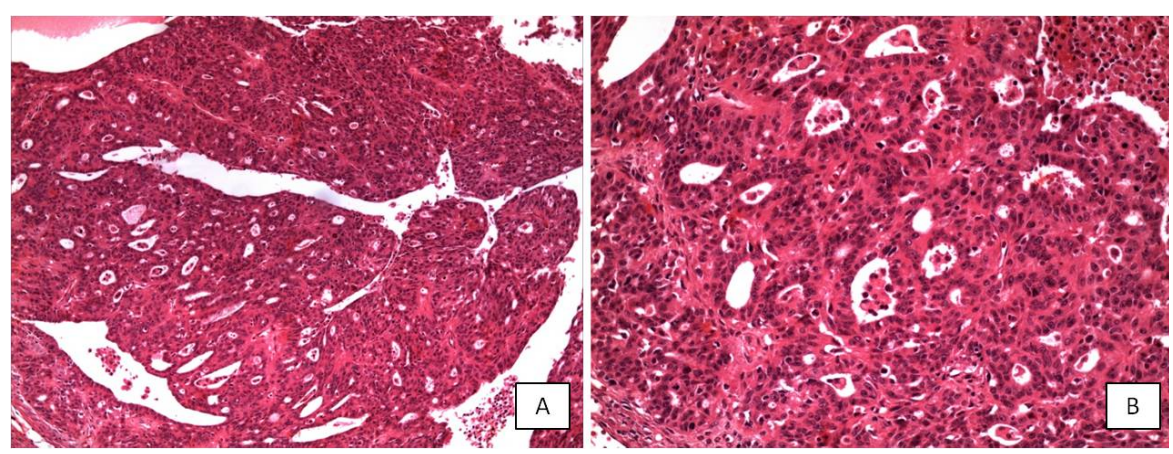

Figure 3: Anastomosing cribriform areas (A) and glands of more columnar cells (B) in compatible with typical endometrioid adenocarcinoma which were focally detected after extensive sampling (H\&E x10, x40). 
Streptavidin-biotin

complex immunodetection system on an automatic immunostainer (Benchmark XT Staining Module, Ventana Medical Systems). Though repeated studies, there was no staining with sex cord stromal markers of inhibin or calretinin. WT1 antibody could not be involved in the panel, which has been known as another marker of sex cord lineage. In contrast with the initial diagnosis, tumor cells showed diffuse and strong positivity with PANCK, CK7, EMA, ER and PR (Fig. 2). Then, extensive sampling was performed and all sections were re-evaluated. Component of typical endometrioid carcinoma with anastomosing cribriform areas of more columnar cells was detected focally (Fig. 3) and the final diagnosis was sertoliform endometrioid adenocarcinoma. Tumor was graded as FIGO grade II depending on the area of typical endometrioid carcinoma and tumor stage was determined as FIGO stage $3 \mathrm{~A}$ with microscopic peritoneal involvement. There was no lymph node involvement and right ovary, uterus, bilateral tuba uterinas and parametrial soft tissues were free of tumor. She received adjuvant chemotherapy consisting three cycles of paclitaxel and carboplatin at threeweek intervals. Currently, at the seventh postoperative month, the patient was well and disease-free.

\section{Discussion}

SEC is a rare variant of endometrioid adenocarcinoma, most of which were reported in the ovary and rare cases in the endometrium (1-14). It causes important diagnostic difficulties for the pathologist due to its morphologic resemblance to sex cord stromal tumors, especially sertoli cell tumor and sertoli leydig cell tumor. It may present with virilising signs occasionally, which may result also in clinical misdiagnosis (4).
Immunohistochemical studies showed the epithelial nature of these sex cord-like cells with EMA, CK positivity and inhibin $\alpha$ negativity, and indicated that this is just a morphologic resemblance in keeping with the present case (4). However dual immunophenotype of these cells with positivity of both epithelial and sex cord markers has been detected in a case of SEC in the endometrium that suggest true sex cord differentiation (16). It has been explained that endometrioid carcinomas, similar to other mullerian tumors, have multipotentiality and can undergo true sex cord differentiation. This dual immunophenotype has not been seen yet in any of the ovarian cases involving the present case (16).

Immunohistochemistry has an important role on the differentiation of these tumors from sex cord stromal tumors, especially when they consist of predominantly sex cord like areas, like the present case. Immunohistochemical markers used for this purpose involve PANCK, LMWCK (CK8/18), CK7, ER, PR, EMA of which positivity were in favour of endometrioid carcinoma and inhibin $\alpha$, calretinin, WT-1 to show sex cord lineage $(4,5,15,17$ 19). Inhibin $\alpha$ and calretinin are highly sensitive and specific markers to show sex cord lineage, being expressed in $82 \%$ to $98 \%$ and $50 \%$ to $60 \%$ of ovarian pure Sertoli cell tumors $(15,20)$. WT-1 has also been suggested for indicating sex cord lineage with high expression rates $(96 \%)$ of pure sertoli cell tumors despite of limited experience for other sex cord stromal tumor types (15). In addition, there have been reports on the utility of CD10 and CD99 for indicating sex cord lineage, however they have been found to have a limited value due to low rates of specifity and sensitivity (15).

In the present case, negativity of Inhibin and calretinin, diffuse and strong positivity of epithelial markers and hormone receptors were the findings which were not keeping with our provisional diagnosis of a sex cord stromal tumour. And the detection of typical endometrioid carcinoma areas with anastomosing cribriform areas of more columnar cells in extensive sampling led to the diagnosis of endometrioid carcinoma.

According to current FIGO grading criteria, SEC may be supposed as a high grade tumor due to the solid appearance of cords and lack of gland formation. However histological grade of the classical endometrioid carcinoma component determinates the behavior of these tumors and it does not differ from that of usual type endometrioid carcinomas of similar grade. The main architecture of the present case also may give rise to an appearance of high grade tumor with solid appearance of cords, anastomosing trabeculae and lack of gland formation, however considering only the very limited area of classical endometrioid carcinoma, it has been evaluated as FIGO grade II.

In conclusion, SEC is a rare variant of endometrioid adenocarcinoma, which causes diagnostic pitfalls due to its resemblance of sex cord stromal tumors. This entity should be kept in mind for all the pathologists dealing with gynecopathology. To reach the right diagnosis, we suggest to sample such tumors extensively and to confirm the diagnosis by immunohistochemistry using an antibody panel involving epithelial markers (PANCK, CK7, EMA), sex cord markers (inhibin $\alpha$, calretinin, WT-1) and hormone receptors (ER, PR) rather than a limited panel. In addition, FIGO grading should be made carefully considering only areas of the classical endometrioid carcinoma, even if very limited and sex-cord like areas should be excluded on the evaluation of histological grade. 


\section{REFERENCES}

1. Young RH, Prat J, Scully RE. Ovarian endometrioid carcinomas resembling sex cord-stromal tumors. A clinicopathological analysis of 13 cases. Am J Surg Pathol. 1982; 6: 513-522

2. Roth LM, Liban E, Czernobilsky B. Ovarian endometrioid tumors mimicking Sertoli and Sertoli-Leydig cell tumors: Sertoliform variant of endometrioid carcinoma. Cancer. 1982; 50: 1322-1331

3. Fox H, Brander WL. A sertoliform endometrioid adenocarcinoma of the endometrium. Histopathology. 1988;13:584-586

4. Ordi J, Schammel DP, Rasekh L, et al.. Sertoliform endometrioid carcinomas of the ovary: a clinicopathologic and immunohistochemical study of 13 cases. Mod Pathol. 1999;12:933-940

5. Guerrieri C, Frånlund B, Malmström H, et al. Ovarian endometrioid carcinomas simulating sex cord-stromal tumors: a study using inhibin and cytokeratin 7 . Int J Gynecol Pathol. 1998;17:266-271

6. Pelkey TJ, Frierson HF Jr, Mills SE, et al. The diagnostic utility of inhibin staining in ovarian neoplasms. Int J Gynecol Pathol. 1998;17:97-105

7. Matadial L, Escoffery CT, BowenChatoor JS. Sertoliform variant of endometrioid carcinoma of the ovary. West Indian Med J. 1995;44:72-73
8. Remadi S, Ismail A, Tawil A, et al. Ovarian sertoliform endometrioid carcinoma. Virchows Arch. 1995;426:533-536

9. Aguirre P, Thor AD, Scully RE. Ovarian endometrioid carcinomas resembling sex cord-stromal tumors. An immunohistochemical study. Int J Gynecol Pathol. 1989;8:364-373

10. Irving JA, Carinelli S, Prat J. Uterine tumors resembling ovarian sex cord tumors are polyphenotypic neoplasms with true sex cord differentiation. Mod Pathol. 2006;19:17-24

11. Murray SK, Clement PB, Young RH. Endometrioid carcinomas of the uterine corpus with sex cord-like formations, hyalinization, and other unusual morphologic features: a report of 31 cases of a neoplasm that may be confused with carcinosarcoma and other uterine neoplasms Am J Surg Pathol. 2005;29:157-166

12. Eichhorn JH, Young RH, Clement PB. Sertoliform endometrial adenocarcinoma: a study of four cases. Int J Gynecol Pathol. 1996;15:119-126

13. Usadi RS, Bentley RC. Endometrioid carcinoma of the endometrium with sertoliform differentiation. Int J Gynecol Pathol. 1995; 14: 360-364

14. Clement PB, Scully RE. Uterine tumors resembling ovarian sex-cord tumors. A clinicopathologic analysis of fourteen cases. Am J Clin Pathol. 1976;66:512-525
15. Zhao C, Bratthauer GL, Barner R, et al. Comparative analysis of alternative and traditional immunohistochemical markers for the distinction of ovarian sertoli cell tumor from endometrioid tumors and carcinoid tumor: A study of 160 cases. Am J Surg Pathol. 2007;31:255-266

16. Liang SX, Patel $K$, Pearl $M$, et al. Sertoliform endometrioid carcinoma of the endometrium with dual immunophenotypes for epithelial membrane antigen and inhibin alpha: case report and literature review. Int J Gynecol Pathol. 2007;26:291-297

17. Berezowski K, Stastny JF, Kornstein MJ. Cytokeratins 7 and 20 and carcinoembryonic antigen in ovarian and colonic carcinoma. Mod Pathol. 1996;9:426-429

18. Chu P, Wu E, Weiss LM. Cytokeratin 7 and cytokeratin 20 expression in epithelial neoplasms: a survey of 435 cases. Mod Pathol. 2000;13:962-972

19. Vang R, Herrmann ME, Tavassoli FA. Comparative immunohistochemical analysis of granulosa and sertoli components in ovarian sex cord-stromal tumors with mixed differentiation: potential implications for derivation of sertoli differentiation in ovarian tumors. Int J Gynecol Pathol. 2004;23:151-161

20. Oliva E, Alvarez T, Young RH. Sertoli cell tumors of the ovary: a clinicopathologic and immunohistochemical study of 54 cases. Am J Surg Pathol. 2005;29:143-156 